\title{
Acer okamotoanum inhibits adipocyte differentiation by the regulation of adipogenesis and lipolysis in 3T3-L1 cells
}

\author{
JI HYUN KIM ${ }^{1}$, SANGHYUN LEE ${ }^{2}$, HYUN YOUNG KIM ${ }^{3}$ and EUN JU CHO ${ }^{1}$ \\ ${ }^{1}$ Department of Food Science and Nutrition and Kimchi Research Institute, Pusan National University, Busan 46241; \\ ${ }^{2}$ Department of Plant Science and Technology, Chung-Ang University, Anseong 17546; ${ }^{3}$ Department of Food Science, \\ Gyeongnam National University of Science and Technology, Jinju 52725, Republic of Korea
}

Received June 28, 2019; Accepted October 4, 2019

DOI: $10.3892 /$ ijmm.2019.4448

\begin{abstract}
Acer okamotoanum is reported to have various antioxidant, anti-inflammatory and beneficial immune system effects. The anti-adipocyte differentiation effects and mechanisms of the ethyl acetate (EtOAc) fraction of an A. okamotoanum extraction was investigated in 3T3-L1 adipocyte cells. Treatment with differentiation inducers increased the level of triglycerides (TGs) in 3T3-L1 adipocyte cells compared with an untreated control. However, the EtOAc fraction of A. okamotoanum significantly decreased TGs. Treatment with $1,2.5$ and $5 \mu \mathrm{g} / \mathrm{ml}$ showed weak activity, but TG production was inhibited at $10 \mu \mathrm{g} / \mathrm{ml}$ compared with the control. In addition, A. okamotoanum caused a significant downregulation of proteins related to adipogenesis, such as $\gamma$-cytidine-cytidine-adenosine-adenosine-thymidine/enhancer binding protein- $\alpha,-\beta$ and peroxisome proliferator-activated receptor- $\gamma$, compared with the untreated control. Furthermore, A. okamotoanum significantly upregulated lipolysis related protein, hormone-sensitive lipase and the phosphorylation of adenosine monophosphate-activated protein kinase (AMPK). Therefore, these results indicate that A. okamotoanum suppressed adipogenesis and increased lipolysis and the activation of AMPK, suggesting a protective role in adipocyte differentiation.
\end{abstract}

\section{Introduction}

Obesity is increasing worldwide. More than 1.9 billion adults are overweight and $13 \%$ of adults are obese (1). Obesity increases the risk of various chronic diseases, such as cardiovascular diseases, arteriosclerosis and type 2 diabetes, which

Correspondence to: Professor Eun Ju Cho, Department of Food Science and Nutrition and Kimchi Research Institute, Pusan National University, 2 Busandaehak-ro 63 beon-gil, Geumjeong-gu, Busan 46241, Republic of Korea

E-mail: ejcho@pusan.ac.kr

Key words: Acer okamotoanum, adipogenesis, AMP kinase, lipolysis, obesity are severe public health problems (2). Obesity is characterized by an accumulation of lipids via increasing adipogenesis, the inhibition of lipolysis and adenosine monophosphate-activated protein kinase (AMPK) activation (3-5). Adipogenesis is the process of differentiation from preadipocytes to mature adipocytes, which is mediated by several adipogenic transcription factors, such as $\gamma$-cytidine-cytidine-adenosine-adenosine-thy midine (CCAAT)/enhancer binding protein (C/EBP)- $\alpha,-\beta$ and peroxisome proliferator-activated receptor (PPAR) $\gamma(6,7)$. The expression of key transcription regulators, including C/EBP- $\alpha$, C/EBP- $\beta$ and PPAR- $\gamma$, activates various adipogenic genes, including fatty acid synthase (FAS), fatty acid binding protein (FABP4), and glucose transporter 4 (GLUT4) $(8,9)$. Furthermore, lipolysis is a catabolic process that hydrolyzes triglycerides (TG) into glycerol and free fatty acids, and it plays a crucial role in balancing the lipid metabolism of adipose cells $(4,10)$. In particular, hormone-sensitive lipase (HSL) is a major lipolysis gene that controls the hydrolysis of TG by its rate-limiting role (10). Moreover, 5'-AMPK is a regulator of energy homeostasis and plays an important role in regulating adipocyte differentiation (5). Activation of AMPK induces fatty acid oxidation, inhibition of fatty acids synthesis and a reduction in the transcription of adipogenic genes such as C/EBP- $\alpha$, C/EBP- $\beta$, and PPAR- $\gamma(5,11)$.

Numerous studies have demonstrated that extracts from plants such as Aster glehni, Eclipta alba and yellow capsicum cause a downregulation of adipogenesis and lipogenesis as well as the induction of lipolysis (12-14). Acer okamotoanum is a plant found on Ulleungdo Island (Korea) and contains a number of antioxidant compounds including cleomiscosins A and C (15). Bioactive flavonoids from A. okamotoanum, including quercitrin, isoquercitrin and afzelin have been previously isolated (16). In addition, the sap of A. okamotoanum is reported to have various biological activities such as antioxidant, immune improvement and anti-hypertension effects (17-19). In addition, the authors previously demonstrated that the ethyl acetate (EtOAc) fraction from A. okamotoanum exhibited antioxidant, neuroprotective and cognitive improvement activities $(20,21)$. According to Kim et al (22), the A. okamotoanum Nakai leaf extract suppressed the expression of PPAR- $\gamma$ and C/EBP- $\alpha$ via the inactivation of phosphatidylinositol 3 kinase $(\mathrm{PI} 3 \mathrm{~K}) /$ protein kinase $\mathrm{B}(\mathrm{Akt})$ signaling and the activation of $\beta$-catenin signaling. Therefore, the A.okamotoanum Nakai leaf 
extract inhibited adipocyte differentiation via adipogenesis in 3T3-L1 cells. Various mechanisms are involved in adipocyte differentiation, such as adipogenesis, lipogenesis, lipolysis and AMPK activation. This study is the first to the best of our knowledge to report on the anti-adipocyte differentiation effects of A. okamotoanum by the regulation of adipogenesis as well as lipolysis and AMPK activation in 3T3-L1 cells.

In the present study, the anti-adipocyte differentiation effect of the EtOAc fraction from A. okamotoanum on the differentiation of 3T3-L1 cells was investigated. Furthermore, the molecular mechanisms in the protective role of adipocyte differentiation of the A. okamotoanum EtOAc fraction were associated with the regulatory pathways of adipogenesis, lipolysis and the activation of AMPK.

\section{Materials and methods}

Reagents. Dulbecco's modified eagle medium (DMEM), bovine calf serum (BCS), fetal bovine serum (FBS), penicillin-streptomycin and trypsin-EDTA solution were purchased from Welgene, Inc. 3-Isobutyl-1-methylxanthine (IBMX), dexamethasone and insulin were purchased from Sigma-Aldrich; Merck KGaA. 3-(4,5-Dimethyl-2-thiazolyl)-2,5-diphenyl-2H-tetrazolium bromide (MTT) was obtained from Bio Basic, Inc., and dimethyl sulfoxide (DMSO) was purchased from Bio Pure.eu $\mathrm{GmbH}$. All primary and secondary antibodies were purchased from Cell Signaling Technology, Inc.

Sample preparation. A. okamotoanum was collected from Ulleung-do, Korea. A voucher specimen was deposited at the Department of Plant Science and Technology, Chung-ang University, Anseong, Korea (Voucher no. LEE 2014-04). The dried aerial portion of A.okamotoanum ( $995.4 \mathrm{~g}$ ) was extracted eight times in methanol $(\mathrm{MeOH})$ using a rotary evaporator. The $\mathrm{MeOH}$ extract was suspended in distilled water and then fractionated and dried successively with n-hexane, $\mathrm{CH}_{2} \mathrm{Cl}_{2}$, EtOAc, and $n$-BuOH. The EtOAc fraction $(35.0 \mathrm{~g})$ was used in the present study (16).

Cell culture and differentiation. The 3T3-L1 pre-adipocyte cells were obtained from the American Type Culture Collection. The cells were cultured in DMEM supplemented with $10 \% \mathrm{BCS}$ and $1 \%$ penicillin-streptomycin at $37^{\circ} \mathrm{C}$ in humidified air with $5 \% \mathrm{CO}_{2}$ in an incubator. To induce differentiation, $100 \%$ confluent 3T3-L1 pre-adipocytes were stimulated with $0.5 \mathrm{mM}$ IBMX, $1 \mu \mathrm{M}$ dexamethasone and $5 \mu \mathrm{g} / \mathrm{ml}$ insulin in DMEM containing 10\% FBS [methylisobutylxanthine, dexamethasone, insulin (MDI) media] for 2 days. The MDI media was replaced with differentiation media $(5 \mu \mathrm{g} / \mathrm{ml}$ insulin in DMEM containing 10\% FBS). The cell culture media was changed 4 times every 2 days.

Cell viability. The 3T3-L1 cells were seeded at a density of $1 \times 10^{5}$ cells $/ \mathrm{ml}$ in a 24 well plate and then incubated for $24 \mathrm{~h}$. Afterward, the EtOAc fraction of A. okamotoanum was added to the test wells at various concentrations $(1-500 \mu \mathrm{g} / \mathrm{ml})$ and then incubated at $37^{\circ} \mathrm{C}$ for $72 \mathrm{~h}$. The cell viability was determined using an MTT assay (23). The MTT solution was replaced with DMEM media $(5 \mathrm{mg} / \mathrm{ml})$ in the wells followed

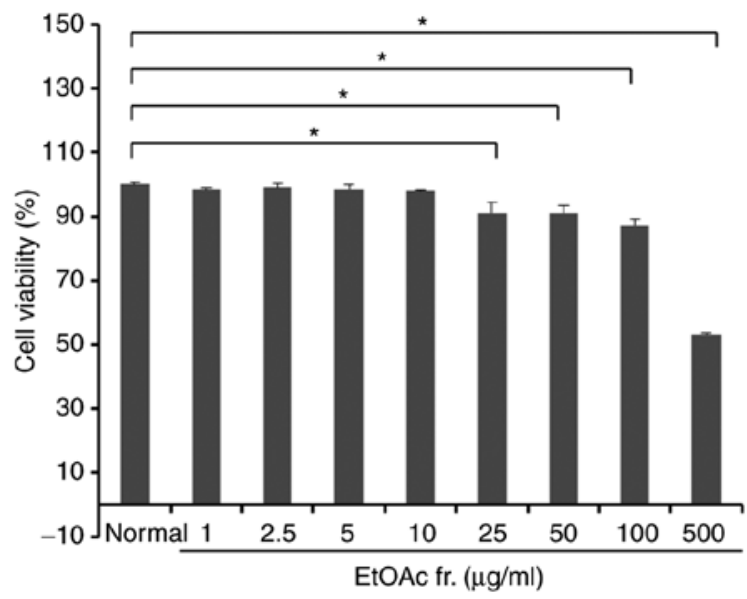

Figure 1. Effects of the EtOAc fraction of Acer okamotoanum on cell viability in 3T3-L1 adipocyte cells. The 3T3-L1 adipocyte cells were pretreated with various concentrations $(1-500 \mu \mathrm{g} / \mathrm{ml})$ of the EtOAc fraction of A. okamotoanum for $72 \mathrm{~h}$. Cell viability was determined by MTT assay. Values are presented as the mean \pm standard deviation. ${ }^{*} \mathrm{P}<0.05$ according to Duncan's multiple range test $(n=6)$. EtOAc, ethyl acetate.

by incubation at $37^{\circ} \mathrm{C}$ for $4 \mathrm{~h}$. The formazan crystals were dissolved in DMSO and the absorbance was read at $540 \mathrm{~nm}$ using a microplate reader (Thermo Fisher Scientific, Inc.).

Oil Red $O$ staining. The cells were washed with PBS, fixed with $10 \%$ formalin at $25^{\circ} \mathrm{C}$ for $10 \mathrm{~min}$ and washed with PBS and 60\% isopropanol. Cells were then stained with $0.6 \%$ Oil Red $\mathrm{O}$ solution at $25^{\circ} \mathrm{C}$ for $20 \mathrm{~min}$, washed 4 times with PBS and $60 \%$ isopropanol, and images were captured. For quantitative analysis, Oil Red O stain was eluted with $100 \%$ isopropanol and quantified by measuring the absorbance at $500 \mathrm{~nm}(24)$.

Western blot analysis. The cells were harvested using a cell scraper and lysed with radioimmunoprecipitation assay buffer (Elpis Biotech, Inc.) containing protease inhibitor cocktail at $4^{\circ} \mathrm{C}$ for $1 \mathrm{~h}$. The protein concentration was determined using a Bio-Rad protein assay (Bio-Rad Laboratories, Inc.). Equal amounts of protein $(15 \mu \mathrm{g})$ were separated with 8-13\% SDS-PAGE and transferred onto a polyvinylidene fluoride membrane. The membrane was blocked with $5 \%$ skim milk at room temperature for $1 \mathrm{~h}$ followed by incubation with the following primary antibodies: $\beta$-actin (cat. no. 8457; 1:1,000), C/EBP- $\alpha$ (cat. no. 2295; 1:200), C/EBP $\beta$ (cat. no. 3087; 1:200), PPAR- $\gamma$ (cat. no. $2430 ; 1: 200$ ), FAS (cat. no. 3189; 1:200), FABP4 (cat.no. 2120; 1:200), GLUT4 (cat. no. 2213; 1:200), phospho-HSL (cat. no. 4126; 1:200), HSL (cat. no. 4107; 1:200), phospho-AMPK (cat. no. 2535; 1:200), or AMPK (cat. no. 2532; 1:200) overnight at $4^{\circ} \mathrm{C}$. Next, the membranes were incubated with the secondary antibodies anti-rabbit $\operatorname{IgG}$ conjugated to horseradish peroxidase (HRP) (cat. no. 7074; 1:500) and anti-mouse IgG conjugated to HRP (cat. no. 7076; 1:500) at room temperature for $1 \mathrm{~h}$, activated with ECL substrate solution (Clarity Western ECL Substrate kit; Bio-Rad Laboratories, Inc.) and visualized with the Davinch-chemi ${ }^{\mathrm{TM}}$ Chemiluminescence Imaging system (Davinch Mini Chemi Q6; Davinch-K Co. Ltd.). Quantification of western blot band intensity was performed using ImageJ software (version 1.51p; National Institutes of Health). 


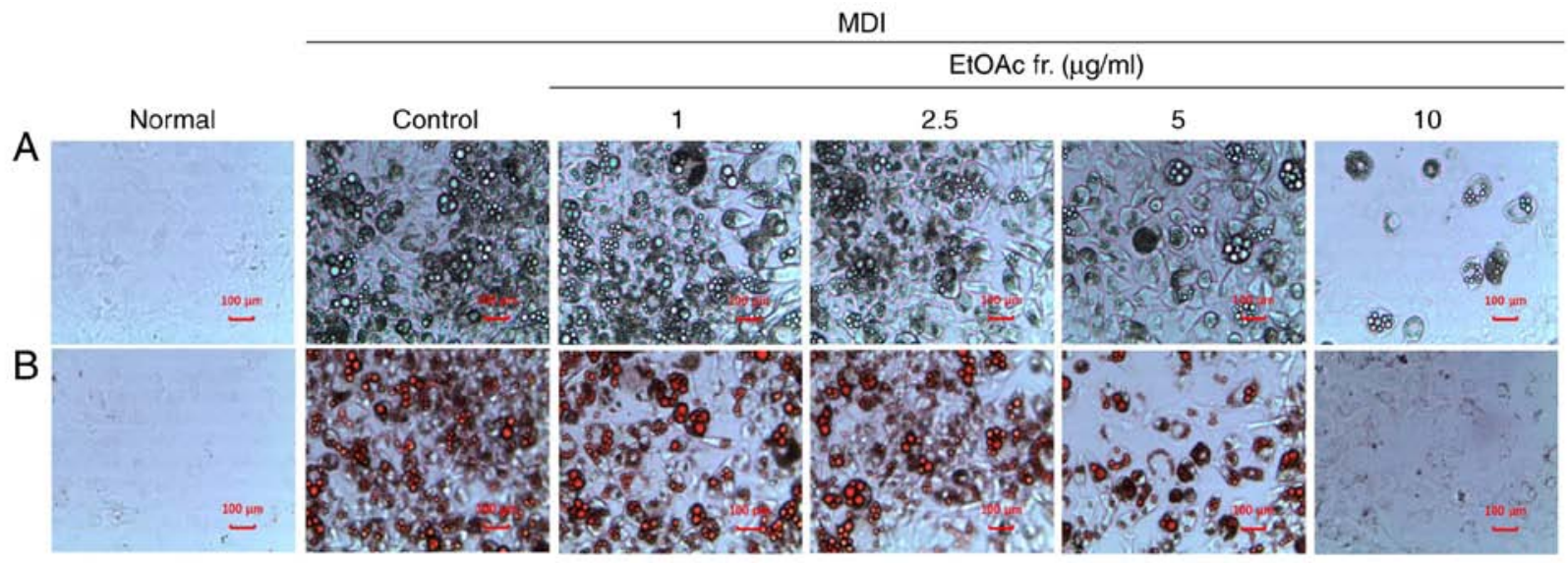

Figure 2. Effects of the EtOAc fraction of Acer okamotoanum on TG accumulation in differentiated 3T3-L1 cells. (A) The 3T3-L1 cells were examined by light microscopy (magnification, x100). (B) Cells were fixed and stained with Oil Red O staining to visualize the lipid droplets by light microscopy (magnification, x100). Scale bar, $100 \mu \mathrm{M}$. EtOAc, ethyl acetate; TG, triglyceride.

Statistical analyses. Each experiment was performed in triplicate $(n=3)$. All data are expressed as the mean \pm standard deviation. The results were assessed by one-way analysis of variance followed by Duncan's multiple range test using IBM SPSS statistics software (version 20.0, IBM Corporation). $\mathrm{P}<0.05$ was considered to indicate a statistically significant difference.

\section{Results}

Effect of A. okamotoanum on 3T3-L1 cell viability. To evaluate the cytotoxicity of the EtOAc fraction of A. okamotoanum on 3T3-L1 cells, cell viability was investigated using an MTT assay. The 3T3-L1 adipocytes were treated with various concentrations $(1-500 \mu \mathrm{g} / \mathrm{ml})$ of the EtOAc fraction of A. okamotoanum for $72 \mathrm{~h}$. As shown in Fig. 1, the EtOAc fraction of A. okamotoanum at concentrations up to $10 \mu \mathrm{g} / \mathrm{ml}$ did not exhibit significant cytotoxicity. However, cell viability was significantly reduced with $25-500 \mu \mathrm{g} / \mathrm{ml}$ of the EtOAc fraction of A. okamotoanum compared with the untreated controls $(\mathrm{P}<0.05)$. Therefore, the EtOAc fractions of A. okamotoanum at concentrations of $1,2.5,5$ and $10 \mu \mathrm{g} / \mathrm{ml}$ were used for further experiments.

Effect of A. okamotoanum on lipid accumulation in 3T3-L1 cells. To confirm whether the EtOAc fraction of A. okamotoanum inhibited adipocyte differentiation, differentiated 3T3-L1 cells were treated with various concentrations $(1,2.5$, 5 or $10 \mu \mathrm{g} / \mathrm{ml}$ ) of the EtOAc fraction of A. okamotoanum. As shown in Fig. 2, the number of lipid droplets increased in MDI-treated differentiated 3T3-L1 cells when compared with the undifferentiated cells. However, treatment with the EtOAc fraction of A. okamotoanum decreased lipid accumulation; this was observed using Oil Red $\mathrm{O}$ staining. In addition, the MDI-treated control had significantly increased intracellular TG levels of 7.76-100.00\% compared with the normal group $(\mathrm{P}<0.05$; Fig. 3). In contrast, the treatment with the EtOAc fraction of A. okamotoanum significantly decreased intracellular TG levels $(\mathrm{P}<0.05)$. The treatment with the EtOAc fraction of A. okamotoanum at doses of $1,2.5$ and $5 \mu \mathrm{g} / \mathrm{ml}$ slightly decreased TG levels to $97.16,91.75$, and $87.29 \%$, respectively.

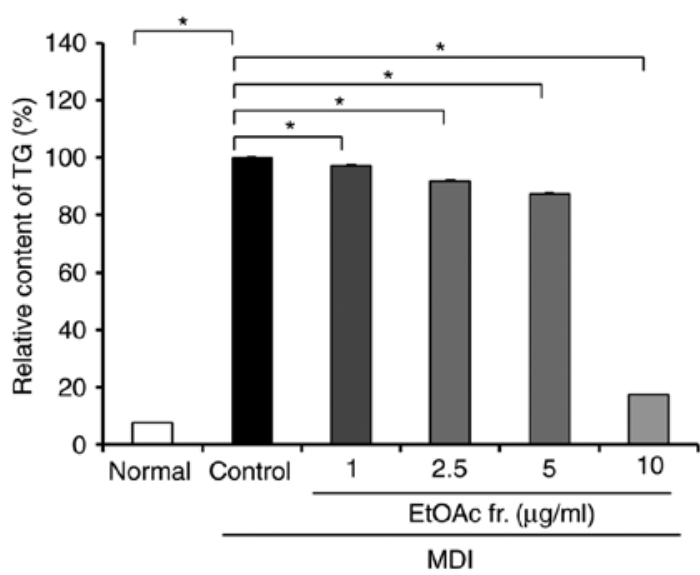

Figure 3. Effects of the EtOAc fraction of Acer okamotoanum on TG accumulation in differentiated 3T3-L1 cells. TG contents of the 3T3-L1 cells were determined by Oil Red $\mathrm{O}$ staining following treatment in the presence or absence of the various concentrations $(1,2.5,5$ or $10 \mu \mathrm{g} / \mathrm{ml})$ of the EtOAc fraction of A. okamotoanum. Values are presented as the mean \pm standard deviation. ${ }^{*} \mathrm{P}<0.05$ according to Duncan's multiple range test $(n=6)$. EtOAc, ethyl acetate; TG, triglyceride.

However, treatment with $10 \mu \mathrm{g} / \mathrm{ml}$ of the EtOAc fraction of A. okamotoanum markedly inhibited TG levels by $17.60 \%$ as compared with the controls.

Effects of A. okamotoanum on the expression of adipogenic transcription factors in 3T3-L1 cells. To investigate the anti-adipogenesis effects of the EtOAc fraction of A. okamotoanum, the protein expression of adipogenic transcription factors, including C/EBP- $\alpha, \mathrm{C} / \mathrm{EB}-\mathrm{P} \beta$ and PPAR- $\gamma$ was measured. As shown in Fig. 4 , the protein levels of C/EBP- $\alpha, \mathrm{C} / \mathrm{EBP}-\beta$ and PPAR- $\gamma$ were significantly upregulated in differentiated 3T3-L1 cells compared with undifferentiated cells $(\mathrm{P}<0.05)$. However, the treatment with the EtOAc fraction of A. okamotoanum inhibited the protein expression of C/EBP- $\alpha$, C/EBP- $\beta$ and PPAR- $\gamma(\mathrm{P}<0.05)$. Of the adipogenic transcription factors, the EtOAc fraction of A. okamotoanum most effectively suppressed $\mathrm{C} / \mathrm{EBP} \beta$ in a dose-dependent manner. 


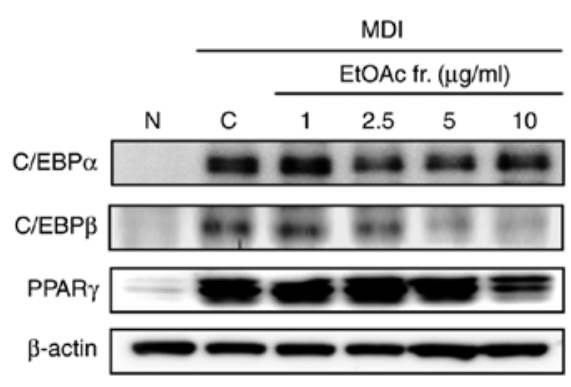

B

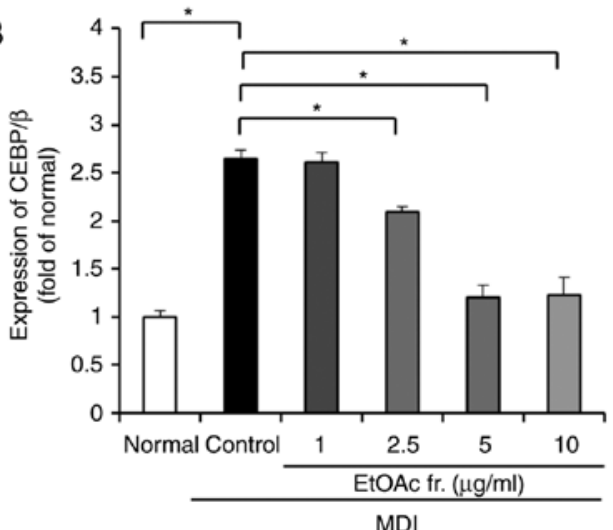

A

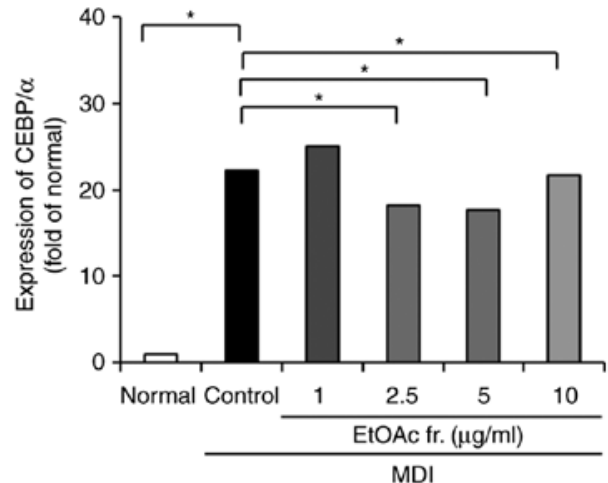

C

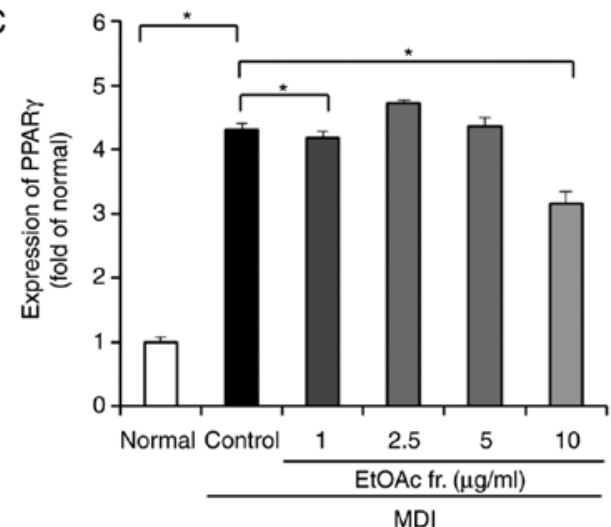

Figure 4. Protein expression levels of adipogenic transcription factors C/EBP- $\alpha$, C/EBP- $\beta$ and PPAR- $\gamma$ in differentiated 3T3-L1 cells. (A) Protein expression of (A) C/EBP- $\alpha$, (B) C/EBP- $\beta$ and (C) PPAR- $\gamma$ in 3T3-L1 cells was determined by western blot analysis following treatment in the presence or absence of the various concentrations $(1,2.5,5$ or $10 \mu \mathrm{g} / \mathrm{ml})$ of the EtOAc fraction of Acer okamotoanum. $\beta$-actin was used as a loading control. " $\mathrm{P}<0.05$ according to Duncan's multiple range test $(\mathrm{n}=3)$. EtOAc, ethyl acetate; C/EBP, $\gamma$-cytidine-cytidine-adenosine-adenosine-thymidine/enhancer binding protein- $\alpha /$ - $\beta$; PPAR- $\gamma$, peroxisome proliferator-activated receptor- $\gamma$.

Effects of A. okamotoanum on adipogenesis-related factors in 3T3-L1 cells. To investigate the effect of the EtOAc fraction of A. okamotoanum on adipogenesis-related factors, the protein expression of FAS, FABP4 and GLUT4 was confirmed (Fig. 5). The protein expression of FAS, FABP4 and GLUT4 were increased in the differentiated 3T3-L1 cells compared with the undifferentiated control cells $(\mathrm{P}<0.05)$. However, the present results revealed that the treatment with the EtOAc fraction of A. okamotoanum at concentrations of 5 and $10 \mu \mathrm{g} / \mathrm{ml}$ significantly downregulated FAS and FABP4 $(\mathrm{P}<0.05)$. GLUT4 protein expression was also significantly decreased by the EtOAc fraction of A.okamotoanum compared with the control $(\mathrm{P}<0.05)$.

Effects of A. okamotoanum on lipolysis related factors in 3T3-L1 cells. The effect of the EtOAc fraction of A. okamotoanum on lipolysis was determined by measuring the protein expression of HSL and phosphorylated HSL (Fig. 6A). The phosphorylation of HSL was significantly reduced in the differentiated 3T3-L1 cells compared with the undifferentiated cells $(\mathrm{P}<0.05)$. Treatment with the EtOAc fraction of A. okamotoanum significantly upregulated the phosphorylation of HSL $(\mathrm{P}<0.05)$.

Effects of A. okamotoanum on activation of AMPK in 3T3-L1 cells. To examine whether the EtOAc fraction of A. okamotoanum affected the activity of AMPK, the levels of AMPK and phosphorylated AMPK were measured (Fig. 6B).
The MDI-treated differentiated 3T3-L1 cells suppressed phosphorylation of AMPK compared with undifferentiated 3T3-L1 cells $(\mathrm{P}<0.05)$. However, the EtOAc fraction of A. okamotoanum significantly increased the phosphorylation of AMPK compared with the control $(\mathrm{P}<0.05)$.

\section{Discussion}

In obesity, the accumulation of lipids and the differentiation of adipocytes in adipose tissue can lead to abnormal lipid metabolism, which can increase the risk of chronic diseases (2). Adipose tissue is dependent on the differentiation of preadipocytes to adipocytes; therefore, 3T3-L1 preadipocytes have been widely used to study the differentiation of adipocytes in vitro (25). During adipocyte differentiation, key adipogenic transcription factors, including C/EBP- $\beta$, C/EBP- $\alpha$ and PPAR- $\gamma$, are activated resulting in intracellular fat accumulation (26). Activation of adipogenic transcription factors induces target genes that determine the phenotypes of mature adipocytes $(26,27)$. These target genes are primarily associated with lipogenesis, TG hydrolysis and glucose and fatty acid metabolism (26,27). Differentiated 3T3-L1 cells treated with MDI mimics the development of obesity in humans and also possesses adipocyte structures similar to live adipose tissue $(25,28)$. In addition, several natural extracts and bioactive compounds have been commonly used to produce anti-obesity effects in a differentiated 3T3-L1 cell model $(12,13)$. The EtOAc fraction of A. okamotoanum 

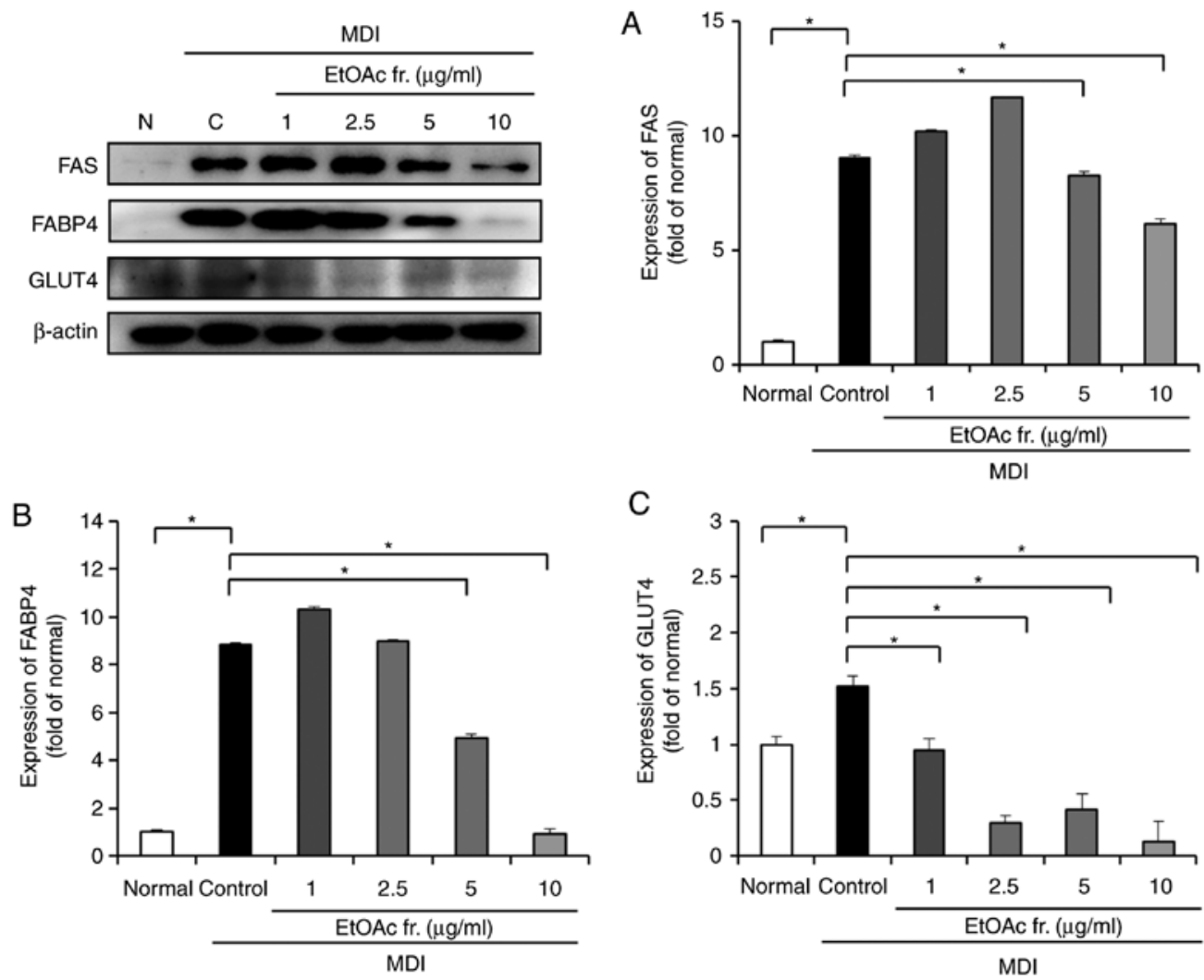

Figure 5. Protein expression levels of adipogenesis-related factors FAS, FABP4 and GLUT4 in differentiated 3T3-L1 cells. Protein expression of (A) FAS, (B) FABP4 and (C) GLUT4 in 3T3-L1 cells was determined by western blot analysis following treatment in the presence or absence of the various concentrations $(1,2.5,5$ or $10 \mu \mathrm{g} / \mathrm{ml})$ of the EtOAc fraction of Acer okamotoanum. $\beta$-actin was used as a loading control. "P<0.05 according to Duncan's multiple range test $(\mathrm{n}=3)$. EtOAc, ethyl acetate; GLUT4, glucose transporter 4; FAS, fatty acid synthase; FABP4, fatty acid binding protein.
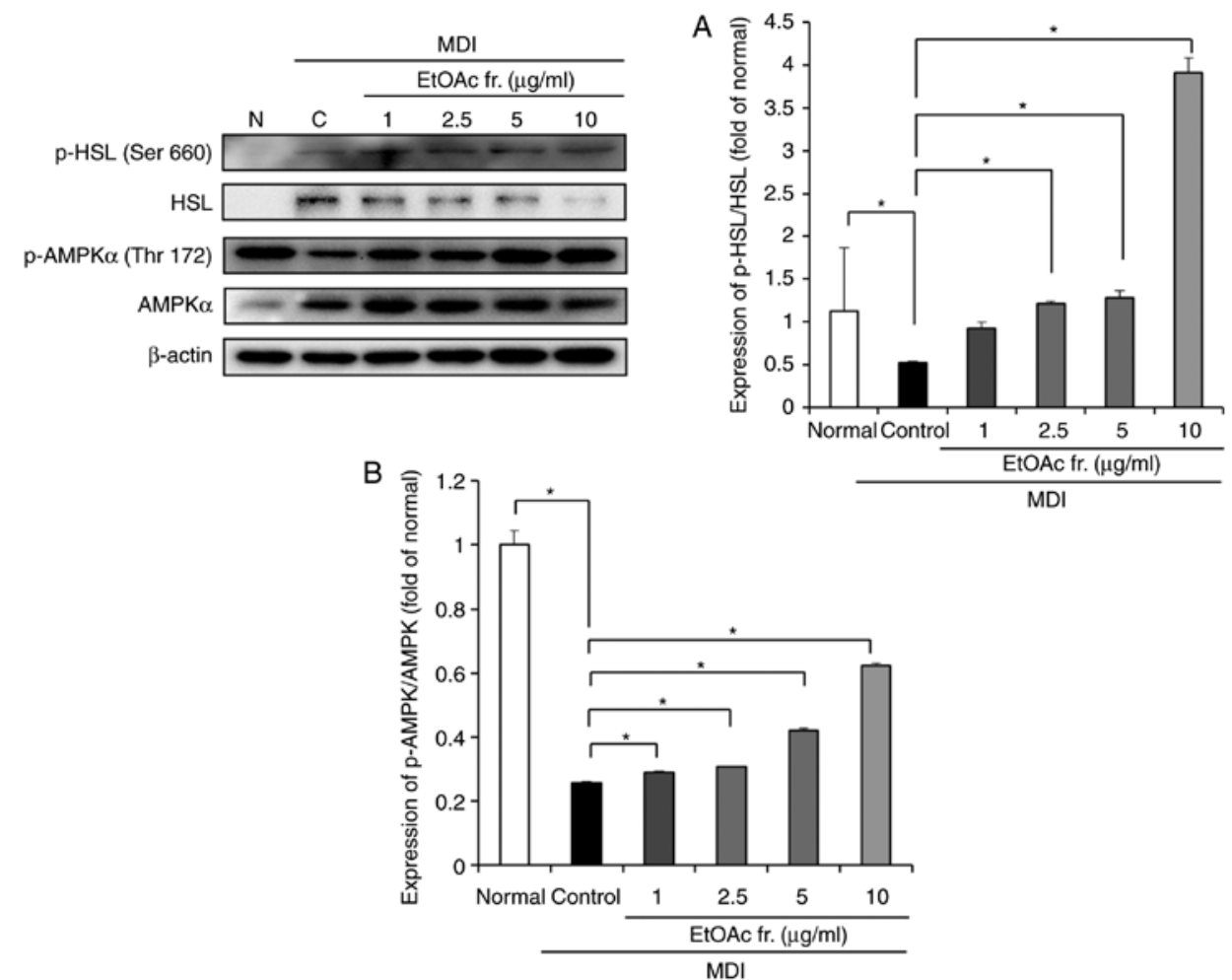

Figure 6. Protein expression levels of lipolysis and AMPK pathway factors p-HSL and HSL, and p-AMPK and AMPK in differentiated 3T3-L1 cells. Protein expression of (A) p-HSL and HSL, and (B) p-AMPK and AMPK in 3T3-L1 cells was determined by western blot analysis following treatment in the presence or absence of the various concentrations $(1,2.5,5$ or $10 \mu \mathrm{g} / \mathrm{ml})$ of the EtOAc fraction of Acer okamotoanum. $\beta$-actin was used as a loading control. ${ }^{*} \mathrm{P}<0.05$ according to Duncan's multiple range test $(\mathrm{n}=3)$. EtOAc, ethyl acetate; $\mathrm{p}$-AMPK, phosphorylated-adenosine monophosphate-activated protein kinase; HSL, hormone-sensitive lipase. 
showed the highest protective effect from free radicals and oxidative stress among other fractions and extracts (20). In addition, the EtOAc fraction from A. okamotoanum exhibited anti-oxidative stress, neuroprotective effects and cognitive improvement activity $(20,21)$. Oxidative stress is closely associated with obesity and antioxidant supplements are beneficial in the management of obesity (29). In addition, the authors previously reported determination of active compounds such as quercitrin, isoquercitrin and afzelin from EtOAc fraction of A. okamotoanum, which had antioxidant activity (16). Therefore, the anti-differentiation effect of the EtOAc fraction of A. okamotoanum and its molecular mechanisms were studied by measuring the expression of adipogenesis and lipolysis-related factors in 3T3-L1 cells.

The present results showed that lipid droplets were markedly increased in differentiated 3T3-L1 cells after stimulation with MDI. However, the EtOAc fraction of A. okamotoanum decreased the lipid droplets in differentiated 3T3-L1 cells Cytotoxicity of the EtOAc fraction of A. okamotoanum was observed. Treatment with the EtOAc fraction of A. okamotoanum at concentrations up to $10 \mu \mathrm{g} / \mathrm{ml}$ did not show significant cytotoxicity compared with untreated control cells; therefore, concentrations of $1,2.5,5$ and $10 \mu \mathrm{g} / \mathrm{ml}$ of the EtOAc fraction of A. okamotoanum were used. TG levels were measured quantitatively. Treatment with the EtOAc fraction of A. okamotoanum at concentrations of 1, 2.5, 5 and $10 \mu \mathrm{g} / \mathrm{ml}$ decreased TGs compared with the control. The inhibitory effect of TG accumulation was dramatically elevated at the concentration of $10 \mu \mathrm{g} / \mathrm{ml}$ and it was relatively weak at the concentrations of $1-5 \mu \mathrm{g} / \mathrm{ml}$. Therefore, it is suggested that $A$. okamotoanum effectively inhibits lipid formation.

Adipogenesis is the differentiation process of adipocytes from preadipocytes and it is characterized by intracellular lipid accumulation. During adipocyte differentiation, key adipogenic transcription factors, such as $\mathrm{C} / \mathrm{EBP}-\alpha, \mathrm{C} / \mathrm{EBP}-\beta$ and PPAR $-\gamma$, are expressed. The expression of $\mathrm{C} / \mathrm{EBP}-\beta$ activates $\mathrm{C} / \mathrm{EBP}-\alpha$, PPAR $-\gamma$ and other adipogenic genes. The over-expression of C/EBP- $\alpha$ and PPAR- $\gamma$ is known to directly affect the development of fat cells (8). In the present study, differentiated 3T3-L1 cells treated with MDI showed an upregulation of key transcription genes related to adipogenesis, including C/EBP- $\alpha, \mathrm{C} / \mathrm{EBP}-\beta$ and PPAR- $\gamma$. However, differentiated 3T3-L1 cells treated with the EtOAc fraction of A. okamotoanum showed downregulation of key transcription genes. The regulatory effect on adipogenesis factors of the EtOAc fraction of A. okamotoanum was not dose-dependent except with C/EBP- $\beta$. The activation of C/EBP- $\alpha$ and PPAR- $\gamma$ are associated with lipid metabolism factors such as FAS, FABP4, and GLUT4. FAS is highly expressed in adipose tissue; therefore, it plays an important role in lipogenesis (30). FAS catalyzes the synthesis of fatty acids and the cytoplasmic storage of TG (30). FABP4, a terminal adipocyte differentiation marker gene, is directly associated with lipogenesis; it induces the accumulation of lipid droplets in the cytoplasm of differentiated 3T3-L1 cells (31). GLUT4 plays a role in lipogenesis through the insulin signaling pathway in differentiated 3T3-L1 adipocytes (32). GLUT4 is involved in the insulin-stimulated glucose uptake by adipose tissue and skeletal muscle, increasing the risk of developing obesity and diabetes (33). The results of the present study indicate that the EtOAc fraction of A. okamotoanum inhibited adipogenesis in adipocytes through the downregulation of FABP4, FAS and GLUT4 in differentiated 3T3-L1 cells.

Lipolysis is the catabolic process of releasing fat from adipose tissue. Lipolysis is the chemical decomposition of TG into glycerol and fatty acids, which blocks lipid accumulation (34). In addition, lipolysis controls lipid homeostasis in adipocytes (34). Therefore, the reduction of lipid accumulation and the increase of lipid catabolism in adipocytes are crucial to the development of anti-obesity agents. During the lipolysis of adipocytes, HSL is an important lipolytic factor. HSL hydrolyzes diglycerides and free fatty acids in TG hydrolysis. HSL is activated via phosphorylation by cAMP-dependent protein kinase A at Ser 660, which stimulates HSL to hydrolyze TGs (35). HSL is a rate-limiting enzyme for lipid mobilization reactions and hydrolyzes diglycerides in the mobilization of TG stored in adipocytes (36). In addition, elevated HSL expression can catalyze adipose lipolysis in response to $\beta$-adrenergic stimulation (37). In this study, treatment with the EtOAc fraction of A. okamotoanum increased lipolysis by upregulation of HSL activation in differentiated 3T3-L1 cells. In particular, the lipolysis factor ratio of phosphorylated-HSL/HSL was upregulated dose-dependently compared with the control. Therefore, it is suggested that the EtOAc fraction of A. okamotoanum could play a potential role in the lipid catabolic process.

The present study also investigated AMPK protein expression in the presence/absence of the EtOAc fraction of A. okamotoanum in differentiated 3T3-L1 cells. AMPK is a metabolic gene that is involved in the regulation of lipid metabolism (38). The activation of AMPK in adipose tissue suppresses lipid synthesis and lipogenesis, regulates fatty acid synthesis, and enhances fatty acid oxidation and glucose transport $(38,39)$. Furthermore, AMPK activity enhances lipolysis by phosphorylation of HSL $(39,40)$. To develop anti-obesity agents, numerous researchers have investigated the AMPK activity of natural extracts and their bioactive compounds in adipocytes $(41,42)$. Therefore, AMPK activity is important to the development of an obesity treatment strategy. In the present study, it was demonstrated that the EtOAc fraction of A. okamotoanum induced the activation of AMPK signaling in differentiated 3T3-L1 cells. This suggests that the EtOAc fraction of A. okamotoanum inhibited adipogenesis and upregulated lipolysis by the regulation of the AMPK signaling pathway. In the present study, the EtOAc fraction of A. okamotoanum inhibited TG accumulation during the differentiation of the 3T3-L1 cells. In addition, A. okamotoanum suppressed adipogenic transcription factors and adipogenesis-related protein expression. Furthermore, A.okamotoanum enhanced the expression of lipolytic proteins, such as HSL and also activated AMPK signaling. Conjugated linoleic acid (CLA) is widely used to treat obesity and it has been reported that CLA is very effective at decreasing body fat accumulation (43). Previous studies demonstrated that CLA inhibited adipocyte differentiation in 3T3-L1 cells by regulation of adipogenesis, lipolysis and AMPK signaling (43-45). Treatment with $10 \mu \mathrm{g} / \mathrm{ml}$ EtOAc fraction of A. okamotoanum inhibited intracellular TGs more effectively than treatment with 3T3-L1 cells with $100 \mu \mathrm{M}$ CLA (43). In addition, A. okamotoanum at concentrations of $10 \mu \mathrm{g} / \mathrm{ml}$ decreased the 
protein expression of PPAR- $\gamma$, which was similar to that in $100 \mu \mathrm{M}$ CLA-treated 3T3-L1 cells (43). Based on these findings, the present study suggested that A. okamotoanum has regulatory activity on adipocyte differentiation and its effect is similar to that of CLA.

Acer (maple) is commonly used in commercial products such as maple syrup and seed oil (46). In addition, several Acer species have been used in traditional medicine for detoxification and to treat rheumatism, eye disease, hepatic diseases, and hemostasis (46). Recently, numerous studies have reported the pharmacological activities of Acer species, including antioxidant, anti-tumor, anti-inflammation, antibacterial, antihyperglycemic, hepatoprotective and anti-obesity activities (46). The EtOAc fraction of A. truncatum Bunge significantly reduced body weight by the inhibition of lipogenesis-related factors such as FAS in vivo $(47,48)$. In addition, Kim et al (22) demonstrated that A. okamotoanum regulated adipocyte differentiation by several molecular mechanisms related to adipogenesis, including PI3K/Akt and $\beta$-catenin/glycogen synthase kinase (GSK) $3 \beta$. A previous study demonstrated that the $\mathrm{MeOH}$ extract of leaves from A.okamotoanum inhibited the phosphorylation of mammalian target of rapamycin and P70S6K by attenuating the PI3K/Akt pathway, thereby suppressing key adipogenic transcription genes (22). In addition, $A$. okamotoanum induced the activation of $\beta$-catenin/GSK $3 \beta$, promoting the downregulation of PPAR- $\gamma$ (22). Therefore, A. okamotoanum inhibits adipogenesis via regulation of $\mathrm{PI} 3 \mathrm{~K} / \mathrm{Akt}$ and $\beta$-catenin/GSK $3 \beta$ signaling. The authors previously isolated and identified flavonoid glycosylates such as isoquercitrin (quercetin-3- $\beta$-D-glucoside; IQ), quercitrin (quercetin-3- $\beta$-D-rhamnoside; QU), and afzelin (keampferol-3-rhamnoside; AF) from the EtOAc fraction of A. okamotoanum (16). IQ inhibited adipocyte differentiation and lipogenesis by the downregulation of adipogenic transcription factors in 3T3-L1 adipocyte cells (49). In addition, IQ exhibited anti-obesity effects by reducing body weight and regulating lipid metabolism in high fat diet-fed mice (49). Furthermore, aglycones of IQ, QU and AF, such as quercetin and kaempferol, showed anti-obesity activity through the regulation of adipogenesis, inflammation, and oxidative stress (50-52). Therefore, flavonoid glycosylates are primarily responsible for the anti-obesity effects of the EtOAc fraction of A. okamotoanum.

In conclusion, the present study suggests that A. okamotoanum inhibits adipocyte differentiation via adipogenesis and lipolysis in cells. A. okamotoanum could be a promising therapeutic agent against obesity, although further in vivo studies must be done.

\section{Acknowledgements}

Not applicable.

\section{Funding}

The present study was supported by Basic Science Research Program through the National Research Foundation of Korea (NRF) funded by the Ministry of Education (grant no. 2015R1D1A1A01058868), Republic of Korea. This study was additionally supported by the Global PH.D Fellowship
Program through the NRF funded by the Ministry of Education (grant no. 2016_H1A2A1906940).

\section{Availability of data and materials}

The datasets used and/or analyzed during the current study are available from the corresponding author on reasonable request.

\section{Authors' contributions}

EJC planned and conceptualized the study. SL and HYK designed the study. SL was involved in the preparation of samples. JHK performed experiments and wrote the manuscript. All authors read and approved the final manuscript.

\section{Ethics approval and consent to participate}

Not applicable.

\section{Patient consent for publication}

Not applicable.

\section{Competing interests}

The authors declare that they have no competing interests.

\section{References}

1. World Health Organization, Media Centre (2017) Obesity and overweight: Key facts. http://www.who.int/mediacentre/factsheets/fs311/en/. Accessed February 16, 2018.

2. Kopelman PG: Obesity as a medical problem. Nature 404: 635-643, 2000

3. Jo J, Gavrilova O, Pack S, Jou W, Mullen S, Sumner AE, Cushman SW and Periwal V: Hypertrophy and/or hyperplasia: Dynamics of adipose tissue growth. PLoS Comput Biol 5: e1000324, 2009.

4. Langin D, Dicker A, Tavernier G, Hoffstedt J, Mairal A, Rydén M, Arner E, Sicard A, Jenkins CM, Viguerie N, et al: Adipocyte lipases and defect of lipolysis in human obesity. Diabetes 54: 3190-3197, 2005.

5. Muoio DM, Seefeld K, Witters LA and Coleman RA: AMP-activated kinase reciprocally regulates triacylglycerol synthesis and fatty acid oxidation in liver and muscle: Evidence that sn-glycerol-3-phosphate acyltransferase is a novel target. Biochem J 338: 783-791, 1999.

6. Cowherd RM, Lyle RE and McGehee RE Jr: Molecular regulation of adipocyte differentiation. Semin Cell Dev Biol 10: 3-10, 1999.

7. Lane MD, Lin FT, MacDougald OA and Vasseur-Cognet M: Control of adipocyte differentiation by CCAAT/enhancer binding protein alpha (C/EBP alpha). Int J Obes Relat Metab Disord 20 (Suppl 3): S91-S96, 1996.

8. Farmer SR: Regulation of PPARgamma activity during adipogenesis. Int J Obes (Lond) 29 (Suppl 1): S13-S16, 2005.

9. Shi Y and Burn P: Lipid metabolic enzymes: Emerging drug targets for the treatment of obesity. Nat Rev Drug Discov 3: 695-710, 2004.

10. Zechner R, Kienesberger PC, Haemmerle G,Zimmermann R and Lass A: Adipose triglyceride lipase and the lipolytic catabolism of cellular fat stores. J Lipid Res 50: 3-21, 2009.

11. Gao Y, Zhou Y, Xu A and Wu D: Effects of an AMP-activated protein kinase inhibitor, compound $\mathrm{C}$, on adipogenic differentiation of 3T3-L1 cells. Biol Pharm Bull 31: 1716-1722, 2008.

12. Lee HM, Yang G, Ahn TG, Kim MD, Nugroho A, Park HJ, Lee KT, Park W and An HJ: Antiadipogenic effects of aster glehni extract: In vivo and in vitro effects. Evid Based Complement Alternat Med 2013: 859624, 2013. 
13. Gupta A, Kumar A, Kumar D, Nandan S, Shankar K, Varshney S, Rajan S, Srivastava A, Gupta S, Kanojiya S, et al: Ethyl acetate fraction of eclipta alba: A potential phytopharmaceutical targeting adipocyte differentiation. Biomed Pharmacother 96: $572-583,2017$

14. Feng Z, Hai-ning Y, Xiao-man C, Zun-chen W, Sheng-rong S and Das UN: Effect of yellow capsicum extract on proliferation and differentiation of 3T3-L1 preadipocytes. Nutrition 30: 319-325, 2014.

15. Jin W, Thuong PT, Su ND, Min BS, Son KH, Chang HW, Kim HP, Kang SS, Sok DE and Bae K: Antioxidant activity of cleomiscosins A and C isolated from Acer okamotoanum. Arch Pharm Res 30: 275-281, 2007.

16. Lee J, Lee DG, Rodriguez JP, Park JY, Cho EJ, Jacinto SD and Lee S: Determination of flavonoids in Acer okamotoanum and their aldose reductase inhibitory activities. Hortic Environ Biotechnol 59: 131-137, 2018

17. Yoo YM, Jung EM, Kang HY, Choi IG, Choi KC and Jeung EB: The sap of Acer okamotoanum decreases serum alcohol levels after acute ethanol ingestion in rats. Int J Mol Med 28: 489-495, 2011.

18. An BS, Kang JH, Yang H, Yang MP and Jeung EB: Effects of Acer okamotoanum sap on the function of polymorphonuclear neutrophilic leukocytes in vitro and in vivo. Mol Med Rep 7: 654-658, 2013

19. Yang H, Hwang I, Koo TH, Ahn HJ, Kim S, Park MJ, Choi WS, Kang HY, Choi IG, Choi KC and Jeung EB: Beneficial effects of Acer okamotoanum sap on L-NAME-induced hypertension-like symptoms in a rat model. Mol Med Rep 5: 427-431, 2012.

20. Choi SY, Kim JH, Lee J, Lee S and Cho EJ: Protective effect of Acer okamotoanum from oxidative stress in C6 glial cells. J Appl Biol Chem 60: 141-147, 2017.

21. Choi SY, Lee J, Lee DG, Lee S and Cho EJ: Acer okamotoanum improves cognition and memory function in A $\beta 25-35$-induced Alzheimer's mice model. Appl Biol Chem 60: 1-9, 2017.

22. Kim EJ, Kang MJ, Seo YB, Nam SW and Kim GD: Acer okamotoanum nakai leaf extract inhibits adipogenesis via suppressing expression of PPAR $\gamma$ and $\mathrm{C} / \mathrm{EBP} \alpha$ in 3T3-L1 cells. J Microbiol Biotechnol 28: 1645-1653, 2018.

23. Mosmann T: Rapid colorimetric assay for cellular growth and survival: Application to proliferation and cytotoxicity assays. J Immunol Methods 65: 55-63, 1983.

24. Ramírez-Zacarías JL, Castro-Muñozledo F and Kuri-Harcuch W: Quantitation of adipose conversion and triglycerides by staining intracytoplasmic lipids with oil red O. Histochemistry 97: 493-497, 1992.

25. Zebisch K, Voigt V, Wabitsch M and Brandsch M: Protocol for effective differentiation of 3T3-L1 cells to adipocytes. Anal Biochem 425: 88-90, 2012

26. Tang QQ, Otto TC and Lane MD: CCAAT/enhancer-binding protein beta is required for mitotic clonal expansion during adipogenesis. Proc Natl Acad Sci USA 100: 850-855, 2003.

27. Moseti D, Regassa A and Kim WK: Molecular regulation of adipogenesis and potential anti-adipogenic bioactive molecules. Int J Mol Sci 17: E124, 2016

28. Ntambi JM and Young-Cheul K: Adipocyte differentiation and gene expression. J Nutr 130: 3122S-3126S, 2000.

29. Abdali D, Samson SE and Grover AK: How effective are antioxidant supplements in obesity and diabetes? Med Princ Pract 24 201-215, 2015.

30. Schmid B, Rippmann JF, Tadayyon M and Hamilton BS: Inhibition of fatty acid synthase prevents preadipocyte differentiation. Biochem Biophys Res Commun 328: 1073-1082, 2005.

31. Gregoire FM, Smas CM and Sul HS: Understanding adipocyte differentiation. Physiol Rev 78: 783-809, 1998.

32. Ma X, Zhang H, Yuan L, Jing H, Thacker P and Li D: CREBL2, interacting with CREB, induces adipogenesis in 3T3-L1 adipocytes. Biochem J 439: 27-38, 2011.

33. Hernandez R, Teruel $\mathrm{T}$ and Lorenzo M: Insulin and dexamethasone induce GLUT4 gene expression in foetal brown adipocytes: Synergistic effect through CCAAT/enhancer-binding protein alpha. Biochem J 372: 617-624, 2003.
34. Shen WJ, Patel S, Miyoshi H, Greenberg AS and Kraemer FB Functional interaction of hormone sensitive lipase and perilipin in lipolysis. J Lipid Res 50: 2306-2313, 2009.

35. Sztalryd C and Kraemer FB: Regulation of hormone-sensitive lipase in streptozotocin-induced diabetic rats. Metabolism 44: 1391-1396, 1995.

36. Zimmermann R, Strauss JG, Haemmerle G, Schoiswohl G, Birner-Gruenberger R, Riederer M, Lass A, Neuberger G, Eisenhaber F, Hermetter A and Zechner R: Fat mobilization in adipose tissue is promoted by adipose triglyceride lipase. Science 306: 1383-1386, 2004

37. Yang X, Zhang X, Heckmann BL, Lu X and Liu J: Relative contribution of adipose triglyceride lipase and hormone-sensitive lipase to tumor necrosis factor- $\alpha(\mathrm{TNF}-\alpha)$-induced lipolysis in adipocytes. J Biol Chem 286: 40477-40485, 2011.

38. Lim CT, Kola B and Korbonits M: AMPK as a mediator of hormonal signalling. J Mol Endocrinol 44: 87-97, 2010.

39. Daval M, Foufelle F and Ferré P: Functions of AMP-activated protein kinase in adipose tissue. J Physiol 574: 55-62, 2006.

40. Gaidhu MP, Fediuc S, Anthony NM, So M, Mirpourian M, Perry RL and Ceddia RB: Prolonged AICAR-induced AMP-kinase activation promotes energy dissipation in white adipocytes: Novel mechanisms integrating HSL and ATGL. J Lipid Res 50: 704-715, 2009.

41. Chen S, Li Z, Li W, Shan Z and Zhu W: Resveratrol inhibits cell differentiation in 3T3-L1 adipocytes via activation of AMPK. Can J Physiol Pharmacol 89: 793-799, 2011.

42. Kang SW, Kang SI, Shin HS, Yoon SA, Kim JH, Ko HC and Kim SJ: Sasa quelpaertensis nakai extract and its constituent p-coumaric acid inhibit adipogenesis in 3T3-L1 cells through activation of the AMPK pathway. Food Chem Toxicol 59: 380-385, 2013

43. Kang K, Liu W, Albright KJ, Park Y and Pariza MW: Trans-10, cis-12 CLA inhibits differentiation of 3T3-L1 adipocytes and decreases PPAR gamma expression. Biochem Biophys Res Commun 303: 795-779, 2003.

44. Moon HS, Lee HG, Seo JH, Chung CS, Kim TG, Kim IY, Lim KW, Seo SJ, Choi YJ and Cho CS: Downregulation of PPARgamma2-induced adipogenesis by PEGylated conjugated linoleic acid as the pro-drug: Attenuation of lipid accumulation and reduction of apoptosis. Arch Biochem Biophys 456: 19-29, 2006.

45. Jiang S, Chen H, Wang Z, Riethoven JJ, Xia Y, Miner J and Fromm M: Activated AMPK and prostaglandins are involved in the response to conjugated linoleic acid and are sufficient to cause lipid reductions in adipocytes. J Nutr Biochem 22: 656-664, 2011

46. Bi W, Gao Y, Shen J, He C, Liu H, Peng Y, Zhang C and Xiao P. Traditional uses, phytochemistry, and pharmacology of the genus Acer (maple): A review. J Ethnopharmacol 189: 31-60, 2016.

47. Zhao WH, Gao LF, Gao W, Yuan YS, Gao CC, Cao LG, $\mathrm{Hu}$ ZZ, Guo JQ and Zhang YX: Weight-reducing effect of Acer truncatum bunge may be related to the inhibition of fatty acid synthase. Nat Prod Res 25: 422-431, 2011.

48. Gao L, Cao L, Tian M and Chen Z: Study on the weight-reducing effect of Acer truncatum leave extract in alimentary obesity rat. Wei Sheng Yan Jiu 41: 609-611, 2012 (In Chinese).

49. Lee CW, Seo JY, Lee J, Choi JW, Cho S, Bae JY, Sohng JK, Kim SO, Kim J and Park YI: 3-O-Glucosylation of quercetin enhances inhibitory effects on the adipocyte differentiation and lipogenesis. Biomed Pharmacother 95: 589-598, 2017.

50. Nabavi SF, Russo GL, Daglia M and Nabavi SM: Role of quercetin as an alternative for obesity treatment: You are what you eat! Food Chem 179: 305-310, 2015.

51. Chen S, Jiang H, Wu X and Fang J: Therapeutic effects of quercetin on inflammation, obesity, and type 2 diabetes. Mediators Inflamm 2016: 9340637, 2016.

52. Lee YJ, Choi HS, Seo MJ, Jeon HJ, Kim KJ and Lee BY: Kaempferol suppresses lipid accumulation by inhibiting early adipogenesis in 3T3-L1 cells and zebrafish. Food Funct 6: 2824-2833, 2015 